\title{
Application of the Behaviour Change Wheel Framework to the development of interventions within the City4Age project
}

\author{
Artur Direito, Susan Michie, Carmen E Lefevre \\ Centre for Behaviour Change \\ University College London \\ London, United Kingdom \\ a.direito@ucl.ac.uk
}

\author{
Emilly I M Collins \\ Information, Decisions and Operations Group \\ University of Bath \\ Bath, United Kingdom \\ e.i.m.collins@bath.ac.uk
}

\begin{abstract}
The probability of an intervention being effective is likely increased if it is designed following a behavioural analysis and with the aid of evidence-based intervention frameworks. For example, the Behaviour Change Wheel (BCW) framework and its associated COM-B model of behaviour have been used successfully as a starting point for designing behaviour change interventions. However, the BCW framework can also be applied at a later stage in the design process, such as when an intervention has been designed but before it is deployed. Here we describe the application of the BCW framework and COM-B model to evaluate and refine already designed interventions. We use a multidisciplinary multi-site project ('City4Age') as a case study. The project aims to promote independent living of older adults through the deployment of interventions using wearable and environment-based technology. We conducted face-to-face interviews with site representatives to identify the target behaviours, perceived barriers and facilitators, intervention functions, and modes of delivery for each planned intervention. Additionally, literature reviews were conducted to identify evidence-based facilitators and barriers for each targeted behaviour. Subsequently, we 1) compared the intervention functions proposed by the project-sites with those most likely to be effective according to the $\mathrm{BCW}$; and 2) assessed the congruency of the barriers and facilitators identified by the pilot-sites with those identified in the literature. For five planned interventions across two project-sites (Birmingham and Singapore), two had intervention functions unlikely to be effective according to the BCW. The two planned interventions to promote social engagement did not address barriers or facilitators evident in the literature, indicating they required refinement. Applying the BCW framework allowed to identify which interventions needed refining. It also helped in providing specific guidance in our recommendations for improvements prior to deployment.
\end{abstract}

Keywords-digital interventions, Behaviour Change Wheel, older adults, COM-B model, intervention design

\section{BACKGROUND}

Today's aging population is putting an increased strain on health services, in part due to rising incidence rates of agerelated conditions such as dementia and frailty [1]. For many older adults, maintaining a healthy lifestyle including physical activity, social interaction and good nutrition can go some way to reduce the risk of developing more serious health conditions. Therefore, identifying ways in which older adults can be encouraged to increase healthy behaviours (e.g. being more active), and reduce unhealthy behaviours (e.g. remaining sedentary for long periods of time) may be beneficial on both an individual and a societal level.

Behaviour change interventions aiming to support older adults in improving their health have demonstrated some success. Previous interventions involving older adults have increased physical activity [2-13], improved nutrition [10,14 16] and increased general well-being [17]. The rise in ownership, affordability and functionality of mobile devices has created further opportunities for interventions that can be applied to older adults [18]. For example, existing interventions have used mobile phones and wearables such as smartwatches to deliver reminders and provide suggestions for activities, and to measure and provide feedback on physical activity [19-22].

Whilst these technological advancements have made delivering interventions and measuring outcomes much easier, it remains important to design interventions in line with existing evidence and theoretical frameworks. One such framework is the Behaviour Change Wheel (BCW) based on the COM-B model of behaviour [23], and incorporating the Theoretical Domains Framework (TDF) [24]. The BCW is a summary of key intervention functions (i.e. what the intervention actually does) and policy categories for implementing interventions, derived from synthesising 19 frameworks of behaviour change across a range of domains, including health [24-27]. It represents a concise way of linking a model of behaviour to a range of intervention functions to change behaviour, linking, in turn, these intervention functions to policy categories that can facilitate each intervention function.

There is evidence that theory based interventions are more effective than non-theory based interventions [28,29]. Therefore, incorporating evidence-based theoretical frameworks may be integral in designing successful interventions. This is normally achieved by consulting the $\mathrm{BCW}$ during the design of the intervention [30]. Conversely, the $\mathrm{BCW}$ has been used to retrospectively categorise interventions [31] in order to assess which are in line with existing theory. However, there are situations in which one may wish to use the BCW after the interventions have been designed but before they are deployed. For example, in large interdisciplinary projects, behavioural 
scientists may be called upon to provide feedback on interventions designed by those developing the technology behind the intervention. In such circumstances, the $\mathrm{BCW}$ will not have been used to design the intervention, but could be used to refine interventions, ensuring they target relevant facilitators (i.e. what makes easier to perform a behaviour) and barriers (i.e. influences preventing the performance of a behaviour) through appropriate intervention functions. To our knowledge, the use of the $\mathrm{BCW}$ at this stage of intervention design has not previously been evaluated. An opportunity to do so was afforded within a multidisciplinary project investigating digital support for older adults: 'City4Age'.

\section{A. City4Age}

The case study for the present paper is City4Age [32], an international, interdisciplinary collaboration aiming to enable ambient, age-friendly cities through the adoption of wearable and environment-based sensors. The project aims to use this sensed behavioural data to enhance early detection of risk factors associated with MCI and frailty, as well as reduce the risk of these conditions by providing behaviour change interventions. The project is ongoing. At the time of writing, the test-beds had selected the behaviours of interest for the interventions but had not yet deployed the interventions. The interventions have been designed by those leading each of the test-beds, without initial input from behavioural scientists. City4Age consequently afforded an opportunity to evaluate whether the BCW framework and COM-B model can also be used to refine already planned interventions.

\section{B. Aims of the paper}

Using the case study of the behavioural interventions planned as part of City4Age, this paper evaluates the application of the Behaviour Change Wheel (BCW) framework and COM$\mathrm{B}$ model to refining already planned digital health interventions for older adults. To this end, we use the BCW and COM-B model to assess:

i. whether the selected intervention functions are appropriate considering the nature of the suggested facilitators and barriers

ii. the appropriateness of the suggested facilitators and barriers, according to existing literature.

\section{Methodology}

\section{A. Classification of planned interventions}

We conducted face-to-face interviews with representatives from each test-bed. On this paper we focus on information from two test-beds, Birmingham and Singapore. From these interviews, we collected information on the number of interventions being proposed by the test-bests, as well as the following information for each of the proposed interventions: target behaviour (i.e. the behaviour that an intervention is aiming to change), barriers and facilitators of that behaviour known to and targeted by the test-bed, what the intervention is proposing to do (e.g. provide reminders) and mode of delivery (e.g. mobile phone, face-to-face). Next, two coders independently categorised the facilitators and barriers named by the test-beds according to the most appropriate COM-B component (physical or psychological capability, physical or social opportunity, or reflective or automatic motivation). Categorisations were then verified and refined by a third coder. In case of disagreement, decisions were reached through discussions between the coders and refinement of the coding scheme.

Following the mapping of the COM-B component(s), the intervention function as planned by the test beds was coded by two independent coders. As the $\mathrm{BCW}$ proposes that specific intervention functions are appropriate for each COM-B component, we next coded whether test-bed proposed intervention functions were appropriate for the COM-B component identified when mapping barriers and facilitators. If the intervention function chosen by the test-bed did not relate to the COM-B component for an intervention, the $\mathrm{BCW}$ was used to identify alternative intervention functions.

\section{B. Behavioural analysis}

1) Topic of the behavioural analysis. Behavioural analyses are a vital part of the process for theoretically driven intervention design [18] as they identify the facilitators and barriers of the behaviour of interest. We conducted a behavioural analysis on social and community engagement and increasing physical activity, two themes of intervention for the test-beds, to assess whether the facilitators and barriers targeted by the test-beds were appropriate for each target behaviour. Here we focus on the behavioural analysis on social and community engagement.

2) Conducting the behavioural analyses. We undertook a scoping review of the literature. Web of Science, PubMed and Google Scholar were searched between 10th September and 25th October 2016, with no time period restrictions. Only published studies in the English language were included. Literature was included if it involved a target population of older adults (over 65 years of age).

3) Mapping the facilitators and barriers to COM-B and $B C W$. Once relevant literature was identified, the facilitators and barriers were extracted from the papers by examining the results and discussion sections of the papers. Each facilitator and barrier was mapped onto the most relevant COM-B component, and then onto the TDF framework by one researcher. The coding was completed by assessing which COM-B and TDF component best represented the facilitator or barrier, as described in the literature. Coding the facilitators and barriers onto the COM-B and TDF components facilitates the selection of the most effective intervention function for each identified barrier, as this decision is made based on the COMB sub-component. 


\section{A. Classification of planned interventions}

TABLE I. THE PROPOSED CITY4AGE INTERVENTIONS FOR THE BIRMINGHAM AND SINGAPORE TEST-BEDS ALONGSIDE RELEVANT COM-B COMPONENTS AND INTERVENTION FUNCTIONS

\begin{tabular}{|c|c|c|c|c|c|c|c|}
\hline Site & The intervention & $\begin{array}{c}\text { Target } \\
\text { behaviour }\end{array}$ & $\begin{array}{c}\text { Current } \\
\text { facilitators \& } \\
\text { barriers }\end{array}$ & $\begin{array}{c}\text { What the } \\
\text { intervention } \\
\text { will do }\end{array}$ & COM-B component & $\begin{array}{l}\text { Intervention } \\
\text { function }\end{array}$ & $\begin{array}{c}\text { Appropriate } \\
\text { intervention } \\
\text { function? }\end{array}$ \\
\hline Birmingham & $\begin{array}{l}\text { "connect to the } \\
\text { local area groups } \\
\text { (reduce social } \\
\text { isolation)" }\end{array}$ & $\begin{array}{l}\text { Increase event } \\
\text { attendance }\end{array}$ & $\begin{array}{l}\text { Elderly people do } \\
\text { not know what } \\
\text { events are } \\
\text { happening, or who } \\
\text { else is going }\end{array}$ & $\begin{array}{l}\text { Reminders, } \\
\text { suggestions }\end{array}$ & Physical Opportunity & Enablement & Yes \\
\hline Birmingham & $\begin{array}{l}\text { "Improve } \\
\text { individual } \\
\text { mobility" }\end{array}$ & $\begin{array}{l}\text { Increasing } \\
\text { walking (number } \\
\text { of steps, speed of } \\
\text { pace) to reduce } \\
\text { risk of frailty }\end{array}$ & $\begin{array}{l}\text { Elderly people do } \\
\text { not have a reason to } \\
\text { walk, anyone to } \\
\text { walk with, or they } \\
\text { do not know the } \\
\text { benefits of walking }\end{array}$ & $\begin{array}{l}\text { Reminders, } \\
\text { suggestions, } \\
\text { information }\end{array}$ & $\begin{array}{l}\text { Social Opportunity / } \\
\text { Psychological Capability }\end{array}$ & $\begin{array}{l}\text { Enablement / } \\
\text { Education }\end{array}$ & Yes \\
\hline Singapore & $\begin{array}{lr}\text { "attend } & \text { social } \\
\text { events } & \text { and } \\
\text { engage } & \text { in } \\
\text { community } & \\
\text { centre activities" }\end{array}$ & $\begin{array}{l}\text { Increase } \\
\text { attendance of } \\
\text { social events to } \\
\text { prevent } \\
\text { loneliness and } \\
\text { increase sense of } \\
\text { community }\end{array}$ & $\begin{array}{l}\text { Not knowing when } \\
\text { events are held, } \\
\text { forgetting when } \\
\text { they are }\end{array}$ & $\begin{array}{l}\text { Phone } \\
\text { reminders }\end{array}$ & Psychological Capability & Enablement & Yes \\
\hline Singapore & $\begin{array}{l}\text { "Invitation to } \\
\text { walk in the } \\
\text { neighbourhood } \\
\text { and visit social } \\
\text { places" }\end{array}$ & $\begin{array}{l}\text { Increase walking } \\
\text { to encourage } \\
\text { them to leave the } \\
\text { home, preventing } \\
\text { loneliness and } \\
\text { physical } \\
\text { inactivity, and } \\
\text { increasing } \\
\text { socialisation }\end{array}$ & $\begin{array}{l}\text { Elderly people lack } \\
\text { encouragement to } \\
\text { walk }\end{array}$ & $\begin{array}{l}\text { Phone } \\
\text { reminders }\end{array}$ & $\begin{array}{l}\text { Social Opportunity } \\
\text { Reflective Motivation }\end{array}$ & Enablement & Yes/No \\
\hline Singapore & $\begin{array}{lr}\text { "invitation } & \text { to } \\
\text { engage } & \text { in } \\
\text { physical activities } \\
\text { at the SAC } \\
\text { (Senior activity } \\
\text { centre)" }\end{array}$ & $\begin{array}{l}\text { Increase physical } \\
\text { activity }\end{array}$ & $\begin{array}{l}\text { Elderly people lack } \\
\text { encouragement to } \\
\text { take part in } \\
\text { physical activity, } \\
\text { and lack } \\
\text { motivation }\end{array}$ & $\begin{array}{l}\text { Phone } \\
\text { reminders, } \\
\text { caregivers } \\
\text { visits }\end{array}$ & $\begin{array}{l}\text { Social Opportunity } \\
\text { Reflective Motivation }\end{array}$ & Enablement & Yes/No \\
\hline
\end{tabular}

Table I shows the proposed interventions for the Birmingham and Singapore test-beds. Out of the 5 interventions, two were found to have an intervention function that did not correspond to those recommended for the relevant COM-B category. The remaining 3 interventions were using appropriate intervention functions for the facilitators and barriers identified by the test-beds.

For the interventions that did not include a recommended intervention function, two COM-B components had been coded due to multiple facilitators or barriers having been suggested. In each case, only one intervention function was proposed by the test-bed. While the proposed intervention function matched one of the identified COM-B components, it was not appropriate for the other COM-B component. One intervention proposed by the Singapore test-bed aimed to increase attendance at physical activity events at the senior centre. The Singapore test-bed specified as barriers that the elderly people lacked encouragement, and were unmotivated. A lack of encouragement relates to the COM-B component of Social Opportunity, and a lack of motivation to Reflective Motivation. We identified that the proposed intervention of providing phone reminders was best mapped onto to the intervention function of Enablement. Enablement is an appropriate intervention function for Social Opportunity, but not for Reflective Motivation. As a consequence, the intervention in its current form is unlikely to adequately target the barrier of a lack of motivation and is therefore less likely to succeed in its aim of increasing attendance at physical activity events, as the intervention is unlikely to influence motivation.

Consequently, to ensure all barriers and facilitators specified by the test-beds are being effectively targeted, we recommended including the additional intervention functions outlined in Table II. The additional suggested intervention functions were selected by consulting the $\mathrm{BCW}$ and identifying what intervention functions are appropriate for the additional barrier's COM-B component. 
TABLE II. SUGGESTED INTERVENTION FUNCTIONS TO BE ADDED TO THOSE INTERVENTIONS REQUIRING IMPROVEMENT

\begin{tabular}{|c|c|c|c|c|c|c|c|}
\hline Site & Intervention & Target behaviour & $\begin{array}{l}\text { Facilitators \& } \\
\text { barriers }\end{array}$ & $\begin{array}{l}\text { Mode of } \\
\text { delivery }\end{array}$ & $\begin{array}{c}\text { COM-B } \\
\text { component }\end{array}$ & $\begin{array}{l}\text { Intervention } \\
\text { function }\end{array}$ & $\begin{array}{c}\text { Suggested } \\
\text { additional } \\
\text { intervention } \\
\text { function } \\
\end{array}$ \\
\hline Singapore & $\begin{array}{l}\text { Invitation to walk in } \\
\text { the neighbourhood } \\
\text { and visit social } \\
\text { places }\end{array}$ & $\begin{array}{l}\text { Increase walking to } \\
\text { encourage them to } \\
\text { leave the home, } \\
\text { preventing loneliness } \\
\text { and physical inactivity, } \\
\text { and increasing } \\
\text { socialisation }\end{array}$ & $\begin{array}{lr}\text { Elderly people lack } \\
\text { encouragement } \\
\text { walk }\end{array}$ & $\begin{array}{l}\text { Phone } \\
\text { reminders }\end{array}$ & $\begin{array}{l}\text { Social } \\
\text { Opportunity / } \\
\text { Reflective } \\
\text { Motivation }\end{array}$ & Enablement & Persuasion \\
\hline Singapore & $\begin{array}{l}\text { invitation to engage } \\
\text { in physical activities } \\
\text { at the SAC (Senior } \\
\text { activity centre) }\end{array}$ & $\begin{array}{ll}\text { Increase } & \text { physical } \\
\text { activity } & \end{array}$ & $\begin{array}{l}\text { Elderly people lack } \\
\text { encouragement to take } \\
\text { part in physical } \\
\text { activity, and lack } \\
\text { motivation }\end{array}$ & $\begin{array}{l}\text { Phone } \\
\text { reminders, } \\
\text { caregivers } \\
\text { visits }\end{array}$ & $\begin{array}{l}\text { Social } \\
\text { Opportunity / } \\
\text { Reflective } \\
\text { Motivation }\end{array}$ & Enablement & Persuasion \\
\hline
\end{tabular}

\section{B. Behavioural analysis}

1) Social and community engagement. The behavioural analysis can be found in Table III. A total of 15 unique papers were identified that met the criteria outlined in the Methods section. Some of these papers identified multiple facilitators or barriers and are therefore listed in the table more than once. The behavioural analysis indicated that the main facilitators to and barriers of social and community engagement are factors relating to transport (e.g. access to public or private transport from the home to the centre), health complaints, selfperceptions and a lack of identification with the identities associated with senior centres (e.g. not feeling "old" enough for senior centres, or seeing attendance as a reminder of aging), and the kinds of activities on offer. These relate to the intervention functions of environmental restructuring (e.g. providing transport to senior centres or improving accessibility or providing additional support for those in ill-health) and modelling (e.g. demonstrating that activities or social events are for people like the recipients). Therefore, based on this behavioural analysis, we suggest that interventions aiming to improve social and community engagement would be the most likely to succeed when providing environmental restructuring and modelling, with a focus on the identified facilitators and barriers.

TABLE III. BEHAVIOURAL ANALYSIS FOR SOCIAL AND COMMUNITY ENGAGEMENT IN OLDER ADULTS AND SUGGESTED INTERVENTION FUNCTIONS

\begin{tabular}{|c|c|c|c|}
\hline COM-B Component & Domain (TDF) & $\begin{array}{l}\text { Literature findings of barriers to and facilitators of the } \\
\text { behaviour }\end{array}$ & $\begin{array}{l}\text { Suggested intervention } \\
\text { function }\end{array}$ \\
\hline $\begin{array}{l}\text { Capability, } \\
\text { Psychological }\end{array}$ & $\begin{array}{l}\text { Memory, Attention and Decision } \\
\text { Processes }\end{array}$ & Attendance reminding them that they are aging [33] & Education \\
\hline Capability, Physical & Skills & $\begin{array}{l}\text { Inability to follow conversations/sensory deficits [34-37], poor } \\
\text { health [38] }\end{array}$ & $\begin{array}{l}\text { Environmental } \\
\text { restructuring }\end{array}$ \\
\hline \multirow[t]{3}{*}{ Opportunity, Social } & \multirow[t]{3}{*}{ Social influences } & Participation of friends/partner [39] & Enablement \\
\hline & & $\begin{array}{l}\text { Lack of local social support }[37], \\
\text { community/perceived lack of acceptance [40] }\end{array}$ & Modelling \\
\hline & & Opportunity to contribute skills/knowledge [41] & Enablement \\
\hline \multirow[t]{4}{*}{$\begin{array}{l}\text { Opportunity, } \\
\text { Physical }\end{array}$} & \multirow[t]{4}{*}{$\begin{array}{l}\text { Environmental Context and } \\
\text { Resources }\end{array}$} & $\begin{array}{l}\text { Lack of appealing activities/social opportunities }[40,42,43], \text { A } \\
\text { choice of activities [41] }\end{array}$ & $\begin{array}{l}\text { Environmental } \\
\text { restructuring }\end{array}$ \\
\hline & & Availability of private car [44] Traffic/poor driving conditions [45] & $\begin{array}{l}\text { Environmental } \\
\text { restructuring }\end{array}$ \\
\hline & & Access to public transport $[43,44,46]$, Cost of public transport [44] & $\begin{array}{l}\text { Environmental } \\
\text { restructuring }\end{array}$ \\
\hline & & Lack of money [46] & $\begin{array}{l}\text { Environmental } \\
\text { restructuring }\end{array}$ \\
\hline \multirow[t]{6}{*}{$\begin{array}{l}\text { Motivation, } \\
\text { Reflective }\end{array}$} & \multirow[t]{2}{*}{$\begin{array}{l}\text { Social/Professional Role and } \\
\text { Identity }\end{array}$} & $\begin{array}{l}\text { Perception that activities are for much older people [33], not self- } \\
\text { identifying as "old" [40] }\end{array}$ & Modelling \\
\hline & & Perception that activities/senior centres are gendered [47] & Modelling \\
\hline & Beliefs about capabilities & Self-perceived health [48] & Education \\
\hline & \multirow[t]{3}{*}{ Beliefs about consequences } & $\begin{array}{l}\text { Perception that engagement and socialising } \\
\text { beneficial/desirable[33,41,43] }\end{array}$ will be & Persuasion \\
\hline & & Fear of social rejection $[40]$ & Education \\
\hline & & Desire to benefit from socialising [43] & Persuasion \\
\hline \multirow{2}{*}{$\begin{array}{l}\text { Motivation, } \\
\text { Automatic }\end{array}$} & \multirow{2}{*}{$\begin{array}{l}\text { Social/Professional Role and } \\
\text { identify }\end{array}$} & Attendance as a reminder of aging [33] & Persuasion \\
\hline & & Activities not catering to preferred social identities [40] & Persuasion \\
\hline
\end{tabular}


The proposed interventions in the area of social and community engagement for the City4Age Birmingham and Singapore test-beds are summarised in Table IV.

TABLE IV. OUTLINE OF THE PROPOSED INTERVENTIONS IN THE AREA OF SOCIAL AND COMMUNITY ENGAGEMENT WITH RELEVANT COM-B COMPONENTS AND INTERVENTION FUNCTIONS

\begin{tabular}{|c|c|c|c|c|c|}
\hline $\begin{array}{l}\text { Test } \\
\text {-bed }\end{array}$ & $\begin{array}{l}\text { Intended } \\
\text { outcome }\end{array}$ & $\begin{array}{c}\text { Relevant } \\
\text { facilitator } \\
\text { s \& } \\
\text { barriers }\end{array}$ & $\begin{array}{c}\text { Proposed } \\
\text { interventi } \\
\text { on } \\
\end{array}$ & $\begin{array}{c}\text { COM- } \\
\text { B } \\
\text { compo } \\
\text { nent } \\
\end{array}$ & $\begin{array}{c}\text { Interve } \\
\text { ntion } \\
\text { functio } \\
\text { n }\end{array}$ \\
\hline $\begin{array}{l}\text { Sing } \\
\text { apor } \\
\text { e }\end{array}$ & $\begin{array}{l}\text { Increased } \\
\text { attendance of } \\
\text { social events at } \\
\text { community } \\
\text { centre }\end{array}$ & $\begin{array}{l}\text { Not } \\
\text { knowing } \\
\text { when } \\
\text { events are } \\
\text { held, } \\
\text { forgetting } \\
\text { when they } \\
\text { are }\end{array}$ & $\begin{array}{l}\text { Reminder } \\
\mathrm{s} \text { on } \\
\text { mobile } \\
\text { phone }\end{array}$ & $\begin{array}{l}\text { Capabil } \\
\text { ity } \\
\text { (Psych } \\
\text { ologica } \\
\text { 1) }\end{array}$ & $\begin{array}{l}\text { Enable } \\
\text { ment }\end{array}$ \\
\hline $\begin{array}{c}\text { Bir } \\
\text { min } \\
\text { gha } \\
\text { m }\end{array}$ & $\begin{array}{l}\text { Increase event } \\
\text { attendance - } \\
\text { connect to the } \\
\text { local area } \\
\text { groups (reduce } \\
\text { social } \\
\text { isolation) }\end{array}$ & $\begin{array}{l}\text { Elderly } \\
\text { people do } \\
\text { not know } \\
\text { what } \\
\text { events are } \\
\text { happening } \\
\text { or who } \\
\text { else is } \\
\text { going }\end{array}$ & $\begin{array}{l}\text { Reminder } \\
\mathrm{s} \text {, } \\
\text { suggestio } \\
\mathrm{ns}\end{array}$ & $\begin{array}{l}\text { Physica } \\
1 \\
\text { Opport } \\
\text { unity/ } \\
\text { Social } \\
\text { Opport } \\
\text { unity }\end{array}$ & $\begin{array}{l}\text { Enable } \\
\text { ment }\end{array}$ \\
\hline
\end{tabular}

The barriers suggested by the test-beds included not knowing what events were being organised, or forgetting when the events were, or not being in the mood for the behaviour. The evidence located in our scoping literature search did not identify a lack of awareness or forgetfulness as main barriers to social or community engagement. However, we did locate literature that suggested the activities being organised were important motivators. Existing evidence suggests that providing more varied and interesting activities operates as a facilitator for social and community engagement. The identified importance of the activities themselves as a facilitator consequently support the suggestion that a lack of interest may be a barrier. Accordingly, if individuals have incorrect or negative perceptions of the kinds of events being organised, communicating the types of events that are occurring may be beneficial to some degree. This intervention will, however, be unlikely to impact those individuals that are genuinely disinterested in the activities. Moreover, as it is not addressing an identified barrier or facilitator directly (as outlined in the literature), it is less likely that the proposed interventions would succeed in the aim of increasing attendance at social events.

\section{Discussion}

The aim of this paper was to evaluate the application of the BCW framework to refine already planned digital health interventions for older adults, using the interventions planned as part of the City4Age project as a case study. We assessed (i) whether the selected intervention functions were appropriate considering the nature of the suggested facilitators and barriers, and (ii) the appropriateness of the suggested facilitators and barriers. This paper demonstrates that the $\mathrm{BCW}$ can be used to refine interventions that have been planned but not yet deployed.
Using the BCW allowed making recommendations for refinement, and provide feedback to the intervention designers. Importantly, the finding that the majority of interventions proposed were based on facilitators and barriers that were not evident in the literature further demonstrate the need for behavioural analyses being conducted prior to the design of the interventions. If the main facilitators and barriers are ignored by the interventions, they may not be able to successfully change the target behaviour.

A limitation of the present paper is that the interventions have not yet been deployed, and therefore have not been evaluated in terms of their effectiveness. Consequently, it remains unclear whether our recommendations will have resulted in more effective interventions. Existing evidence suggests that ensuring interventions are aligned with evidencebased theoretical frameworks increases the likelihood of the intervention successfully changing behaviour [28,29]. Therefore, adapting interventions to better align with the $\mathrm{BCW}$ will strengthen the interventions.

\section{ACKNOWLEDGMENTS}

This project has received funding from the European Union's Horizon 2020 research and innovation programme under grant agreement No 689731.

\section{REFERENCES}

[1] Christensen K, Doblhammer G, Rau R, Vaupel JW. Ageing populations: the challenges ahead. Lancet. Elsevier Ltd; 2009;374(9696):1196-1208. PMID: 19801098

[2] McAuley E, Jerome GJ, Elavsky S, Marquez DX, Ramsey SN. Predicting long-term maintenance of physical activity in older adults. Prev Med (Baltim). 2003;37(2):110-118.

[3] Irvine AB, Gelatt VA, Seeley JR, Macfarlane P, Gau JM. Web-based intervention to promote physical activity by sedentary older adults: randomized controlled trial. J Med Internet Res. JMIR Publications Inc., Toronto, Canada; 2013;15(2):e19.

[4] van Stralen MM, Kok G, de Vries H, Mudde AN, Bolman C, Lechner L. The Active plus protocol: systematic development of two theory-and evidence-based tailored physical activity interventions for the over-fifties. BMC Public Health. BioMed Central; 2008;8(1):399.

[5] van Stralen MM, de Vries H, Bolman C, Mudde AN, Lechner L. Exploring the efficacy and moderators of two computer-tailored physical activity interventions for older adults: a randomized controlled trial. Ann Behav Med. Springer; 2010;39(2):139-150.

[6] van Stralen MM, de Vries H, Mudde AN, Bolman C, Lechner L. The working mechanisms of an environmentally tailored physical activity intervention for older adults: a randomized controlled trial. Int J Behav Nutr Phys Act. BioMed Central; 2009;6(1):83.

[7] van Stralen MM, de Vries H, Mudde AN, Bolman C, Lechner L. The longterm efficacy of two computer-tailored physical activity interventions for older adults: main effects and mediators. Heal Psychol. American Psychological Association; 2011;30(4):442.

[8] Pinto BM, Lynn H, Marcus BH, DePue J, Goldstein MG. Physician-based activity counseling: intervention effects on mediators of motivational readiness for physical activity. Ann Behav Med. Springer; 2001;23(1):210 .

[9] Nahm E, Resnick B, Covington B. Development of theory-based, online health learning modules for older adults: Lessons learned. CIN Comput Informatics, Nurs. LWW; 2006;24(5):261-268.

[10] Clark PG, Rossi JS, Greaney ML, Riebe DA, Greene GW, Saunders SD, et al. Intervening on exercise and nutrition in older adults The Rhode Island SENIOR Project. J Aging Health. Sage Publications; 2005;17(6):753-778. 
[11] Greaney ML, Riebe D, Garber CE, Rossi JS, Lees FD, Burbank PA, et al. Long-term effects of a stage-based intervention for changing exercise intentions and behavior in older adults. Gerontologist. Oxford University Press; 2008;48(3):358-367.

[12] Clark DO, Stump TE, Damush TM. Outcomes of an exercise program for older women recruited through primary care. J Aging Health. Sage Publications; 2003;15(3):567-585

[13] Buman MP, Giacobbi Jr PR, Dzierzewski JM, Morgan AA, McCrae CS, Roberts BL, et al. Peer volunteers improve long-term maintenance of physical activity with older adults: a randomized controlled trial. J Phys Act Heal. 2011;8(s2):S257-S266.

[14] Walker SN, Pullen CH, Boeckner L, Hageman PA, Hertzog M, Oberdorfer MK, et al. Clinical trial of tailored activity and eating newsletters with older rural women. Nurs Res. 2009;58.

[15] Zazpe I, Sanchez-Tainta A, Estruch R, Lamuela-Raventos RM, Schröder $\mathrm{H}$, Salas-Salvado J, et al. A Large Randomized Individual and Group Intervention Conducted by Registered Dietitians Increased Adherence to Mediterranean-Type Diets: The PREDIMED Study. J Am Diet Assoc. 2008;108(7):1134-1144.

[16] Rejeski WJ, Mihalko SL, Ambrosius WT, Bearon LB, McClelland JW. Weight Loss and Self-Regulatory Eating Efficacy in Older Adults: The Cooperative Lifestyle Intervention Program. Journals Gerontol Ser B. 2011;66B(3):279-286

[17] Spirduso WW, Cronin DL. Exercise dose-response effects on quality of life and independent living in older adults. Med Sci Sport Exerc. Lippincott Williams \& Wilkins; 2001;

[18] West R, Michie S. A Guide to Development and Evaluation of Digital Behaviour Change Interventions in Healthcare. London: Silverback Publishing; 2016.

[19] King AC, Hekler EB, Grieco LA, Winter SJ, Sheats JL, Buman MP, et al. Harnessing Different Motivational Frames via Mobile Phones to Promote Daily Physical Activity and Reduce Sedentary Behavior in Aging Adults. PLoS One. 2013;8(4):2-9. PMID: 23638127

[20] McMahon SK, Lewis B, Oakes M, Guan W, Wyman JF, Rothman AJ. Older Adults' Experiences Using a Commercially Available Monitor to Self-Track Their Physical Activity. Eysenbach G, editor. JMIR mHealth uHealth. Toronto, Canada: JMIR Publications Inc.; 2016;4(2):e35. PMID: 27076486

[21] Quinn CC, Khokhar B, Weed K, Barr E, Gruber-Baldini AL. Older Adult Self-Efficacy Study of Mobile Phone Diabetes Management. Diabetes Technol Ther. 2015;17(7):455-461.

[22] Murphy SL. Review of physical activity measurement using accelerometers in older adults: considerations for research design and conduct. Prev Med (Baltim). United States; 2009;48(2):108-114. PMID: 19111780

[23] Michie S, van Stralen MM, West R. The behaviour change wheel: A new method for characterising and designing behaviour change interventions. Implement Sci. BioMed Central Ltd; 2011;6(1):42. PMID: 21513547

[24] Francis JJ, O'Connor D, Curran J. Theories of behaviour change synthesised into a set of theoretical groupings: introducing a thematic series on the theoretical domains framework. Implement Sci. 2012;7(1):35. PMID: 22531601

[25] French SDS, Green SSE, O'Connor DA Da, McKenzie JEJ, Francis JJ, Michie S, et al. Developing theory-informed behaviour change interventions to implement evidence into practice: a systematic approach using the Theoretical Domains Framework. Implement Sci. England: ???; 2012;7(1):38. PMID: 22531013

[26] Michie S, Johnston M, Francis J, Hardeman W, Eccles M. From Theory to Intervention: Mapping Theoretically Derived Behavioural Determinants to Behaviour Change Techniques. Appl Psychol. 2008;57(4):660-680.

[27] Michie S, Wood CE, Johnston M, Abraham C, Francis JJ, Hardeman W. Behaviour change techniques: the development and evaluation of a taxonomic method for reporting and describing behaviour change interventions (a suite of five studies involving consensus methods, randomised controlled trials and analysis of qualitative da. Health Technol Assess (Rockv). 2015;

[28] Taylor N, Conner M, Lawton R. The impact of theory on the effectiveness of worksite physical activity interventions: a meta-analysis and metaregression. Health Psychol Rev. Routledge; 2012;6(1):33-73.

[29] Bailey J V, Murray E, Rait G, Mercer CH, Morris RW, Peacock R, et al. Interactive computer-based interventions for sexual health promotion. In: Bailey J V, editor. Cochrane Database Syst Rev. Chichester, UK: John Wiley \& Sons, Ltd; 2010.

[30] Porcheret M, Main C, Croft P, McKinley R, Hassell A, Dziedzic K Development of a behaviour change intervention: a case study on the practical application of theory. Implement Sci. 2014;9(1):42.

[31] Gardner B, Smith L, Lorencatto F, Hamer M, Biddle SJH. How to reduce sitting time? A review of behaviour change strategies used in sedentary behaviour reduction interventions among adults. Health Psychol Rev. Routledge; 2016;10(1):89-112.

[32] City4Age [Internet].

[33] Lund A, Engelsrud G. "I am not that old": Inter-personal experiences of thriving and threats at a senior centre. Ageing Soc. Cambridge, UK, UK: Cambridge University Press; 2008;28(5):675-692.

[34] Marsiske M, Delius J, Maas I, Lindenberger U, Scherer H, Tesch-Römer C. Sensory systems in old age. Berlin aging study Aging from. 1999;70:360-383.

[35] Crews JE, Campbell VA. Vision impairment and hearing loss among community-dwelling older Americans: implications for health and functioning. Am J Public Health. American Public Health Association; 2004;94(5):823-829.

[36] Wallhagen MI, Strawbridge WJ, Shema SJ, Kurata J, Kaplan GA Comparative impact of hearing and vision impairment on subsequent functioning. J Am Geriatr Soc. Wiley Online Library; 2001;49(8):10861092.

[37] Mc Laughin D, Adams JON, Dimitros V, Dobson A, Laughlin DMC, Adams JON, et al. Factors which enhance or inhibit social support: mixed-methods analysis of social networks in older women. Ageing Soc. 2011;31(1):18-33. PMID: 55781388

[38] Jivraj S, Nazroo J, Barnes M. Short- and long-term determinants of social detachment in later life. 2016;

[39] Toepoel V. Ageing, Leisure, and Social Connectedness: How could Leisure Help Reduce Social Isolation of Older People? Soc Indic Res. 2013;113(1):355-372. PMID: 23874058

[40] Goll JC, Charlesworth G, Scior K, Stott J. Barriers to social participation among lonely older adults: The influence of social fears and identity. PLoS One. 2015;10(2):1-17. PMID: 25706933

[41] MacKean R, Abbott-Chapman J. Older people's perceived health and wellbeing: The contribution of peer-run community-based organisations. Heal Sociol Rev. Taylor \& Francis; 2012;21(1):47-57.

[42] Walker J, Orpin P, Baynes H, Stratford E, Boyer K, Mahjouri N, et al Insights and principles for supporting social engagement in rural older people. Ageing Soc. Cambridge, UK, UK: Cambridge University Press; 2012;33(6):938-963.

[43] Pardasani M. Senior centers: characteristics of participants and nonparticipants. Act Adapt Aging. 2010;34(1):48-70.

[44] Shergold I, Parkhurst G, Musselwhite C. Rural car dependence: an emerging barrier to community activity for older people. Transp Plan Technol. 2012;35(1):69-85.

[45] Age Concern. Promoting mental health and well-being in later life. London Ment Heal Found Age Concern. 2006,

[46] Barnes M, Oliveira C De, Hussey D, Phelps A. The Dynamics of Ageing, Evidence from the English Longiudinal Study of Ageing. Soc Sci. 2012.

[47] Marhankova JH. "Women are just more active" - gender as a determining factor in involvement in senior centres. Ageing Soc. Cambridge, UK, UK: Cambridge University Press; 2013;34(9):1482-1504.

[48] Kohli M, Hank K, Kunemund H, Künemund H. The social connectedness of older Europeans: patterns, dynamics and contexts. J Eur Soc Policy. 2009; 19(4):327-340. 